\title{
ENERGY AND COST FOR PELLETING AND TRANSPORTATION of SELECT CELlulosic Biomass FeEDSTOCKS FOR ETHANOL PRODUCTION
}

\author{
J. M. Wilson, L. J. McKinney, K. Theerarattananoon, T. C. Ballard, \\ D. Wang, S.A. Staggenborg, P. V. Vadlani
}

\begin{abstract}
The current forage handling equipment in the cellulosic ethanol industry is severely limited by the low bulk density of baled and ground biomass. Low bulk density contributes to flowability problems and lack of maximizing trailer capacities. Biomass pelleting process can improve the bulk density and flowability characteristics of forages. The objectives of this research were to evaluate: (1) the energy requirements of grinding sorghum stalks, corn stover, wheat straw, and big bluestem through two different screen size openings, (2) the energy requirements of pelleting forages from the two grind sizes, (3) the physical properties of pelleted biomass, and (4) the costs associated with biomass processing, transportation, and storage. The two mill screen size openings $(3.2$ and $6.5 \mathrm{~mm})$ were found to have significantly different energy consumptions for grinding step from each other. All four forage types, except for big bluestem and corn stover, were also found to have significantly different energy consumptions for grinding. Production rate through the $6.5 \mathrm{~mm}$ screen was almost three times higher than that of the $3.2 \mathrm{~mm}$ screen (average of $181.4 \mathrm{vs} .68 \mathrm{~kg} / \mathrm{h}$ ). Hammermill screen size opening (i.e., grind size) was found to have significant effects on energy consumption for pelleting process. The four forage types were also found to have significantly different energy consumptions from each other, except for big bluestem versus wheat straw $(P=0.1192$ ). Particle length for the $3.2 \mathrm{~mm}$ grind ranged from 0.15 to $0.18 \mathrm{~cm}$, while the 6.5 -mm grind ranged from 0.20 to $0.31 \mathrm{~cm}$. Pelleting increased bulk density from 99.96 to $160.02 \mathrm{~kg} / \mathrm{m}^{3}$ for raw biomass grinds to 499.30 to $701.13 \mathrm{~kg} / \mathrm{m}^{3}$ for pelleted biomass. Pellet durability ranged from 93\% to 98\%. A cost analysis indicated that it would take roughly \$22 extra per metric ton for the transportation, pre-processing, and storage of pelleted cellulosic biomass than corn grain. This cost is still almost half that of the cost for baled biomass.
\end{abstract}

Keywords. Biomass pellets, Bulk density, Cellulosic ethanol, Electrical energy, Logistics.

T The current forage handling equipment in the cellulosic ethanol industry is severely limited by the low bulk density of baled or ground biomass. Low bulk density can contribute to flowability problems and the lack of maximizing trailer capacities. Ethanol plants, in their current form, are not designed to handle material with these physical properties. Grinding and pelleting forages can increase their bulk density; thereby, reducing flowability and weight concerns. If a system were developed that would take the burden of

Submitted for review in April 2012 as manuscript number FPE 9719; approved for publication by the Food \& Process Engineering Institute of ASABE in November 2013.

The authors are Jonathan M. Wilson, Graduate Research Assistant, Department of Grain Science and Industry, Leland J. McKinney, Associate Professor, Department of Grain Science and Industry, Karnnalin Theerarattananoon, Graduate Research Assistant, Department of Biological and Agricultural Engineering, Todd Ballard, Graduate Research Assistant, Department of Agronomy, Donghai Wang, ASABE Member, Professor, Department of Biological and Agricultural Engineering, Scott Staggenborg, Professor, Department of Agronomy, Praveen Vadlani, Professor, Department of Grain Science and Industry, Department of Grain Science and Industry, Kansas State University, Manhattan, Kansas. Corresponding author: Jonathan M. Wilson, Department of Grain Science and Industry, Kansas State University, Manhattan, KS 66506; phone: 785-532-3775; email: jwilson@ksu.edu. handling inefficient, unprocessed biomass off of the ethanol plant, it could greatly increase the feasibility of biomassbased fuels by allowing for additional plant throughput and reduce the amount of inputs, most importantly labor, required to produce cellulosic based ethanol.

Cost and logistics analysis have been developed by Sokhansanj et al. (2006a, 2006b), Hess et al. (2007), Mukunda (2007), and Krishnakumar and Ileleji (2010). These models account for a variety of different operating conditions and storage scenarios, but all agree that it is unlikely that plants will have enough on-hand storage for forages year round and product degradation is a major concern.

The effectiveness and feasibility of cellulosic biomass as an energy source for ethanol production is limited by the current harvesting/processing equipment, transportation system, and storage systems currently available for on-farm use. The low bulk density characteristics of baled and ground biomass make it hard to handle and transport in large quantities that would be required for commercial ethanol production. Using an existing corn ethanol plant in Indiana, Mukunda (2007) showed that transportation is the largest component of the logistics cost of delivering biomass from the farm production centers to the plant processing centers. 
Biomass utilized for ethanol would most likely require a storage facility before delivery to the ethanol plant in order to prevent degradation of the cellulose content due to weather. This would require a large amount of shed space or full poly wrapped bales, neither of which is cost effective for this processing situation. In regards to feedstock storage, Cushman et al. (2003) mentioned that storage systems (such as baling, compacting, or pelleting) need to increase feedstock density by 2.5 times in order to be considered relevant. A similar target was set for preprocessing, which included the development of methods to increase biomass availability through effective year round storage methods. If biomass from any source can be pelleted and stored in grain storage facilities, then a pelleting system could be utilized at different times of the year to pellet and store numerous sources, such as cool season grasses in early spring, wheat, barley and oat straw during the summer, corn and grain sorghum stalks in the fall, and perennial grasses such as switchgrass in the early winter.

Another limitation is the inability to maximize payload due to the bulk density. Tractor/trailers are regulated based on volume and weight. Ideally, we would reach the weight rating before maximizing volume in order to haul the most material possible. If a tractor/trailer were capable of hauling $31.18 \mathrm{~m}^{3}$ of product, it would hold $22,473 \mathrm{~kg}$ of corn at $720.83 \mathrm{~kg} / \mathrm{m}^{3}$, or $3,995.2 \mathrm{~kg}$ of ground forages at $128.15 \mathrm{~kg} / \mathrm{m}^{3}$. Increasing the bulk density through additional processing, can have a significant impact on our bottom line and also increase the distances we can afford to transport product.

A pilot study (Hess et al., 2006) of a straw-based ethanol plant reported that at feedstock bulk densities of $128 \mathrm{~kg} / \mathrm{m}^{3}$, $80 \%$ of the feedstocks available within a $161 \mathrm{~km}(100 \mathrm{mile})$ radius of the plant must be delivered to the plant. To reduce transportation costs, $76 \%$ must come from within $80 \mathrm{~km}$ of the plant; $17 \%$ from 80 to $120 \mathrm{~km}$ of the plant; and $12 \%$ from 120 to $160 \mathrm{~km}$ of the plant to supply $105 \%$ of demand. If transportation costs can be reduced by increasing feedstock density, it is possible that these percentages can be reduced and the radius that feedstocks are drawn from can be increased to ease the pressure on fields near the biorefinery to supply feedstocks.

Biomass particle size reduction increases bulk density, improves flow properties, and increases porosity and surface area (Drzymala, 1993). Particle size reduction also aids in the utilization efficiencies of animal and microbial digestion by exposing additional surface area for degradation by acids and enzymes. Size reduction accounts for a huge portion of the power requirements needed for the conversion of cellulose into ethanol. Energy requirements for grinding depend on its initial particle size, moisture content, material properties, machine throughput, and other machine variables (Mani et al., 2004).

The poor flow characteristics and bulk densities of ground biomass prevent it from flowing properly during the unloading, storage, and transfer operations at a biorefinery. These flow characteristics would require biorefineries to install specialized equipment and would make retrofitting existing corn-based ethanol plants into cellulosic ethanol plants almost impossible. The added cost of the new equipment could be reduced or eliminated if the bulk density of the feedstock can be increased prior to delivery. Other costs associated with handling a low bulk density feedstock are the additional conveyor capacity and storage area required.

Krishnakumar and Ileleji (2010) summarized the costs of pre-processing corn grain, corn stover pellets and bales, and switchgrass pellets and bales for ethanol conversion. Their analysis assumed that forages would be transported from the field to a pelleting and cooling substation then transported to the ethanol facilities. By moving the grinding and pelleting operation to the field we could dramatically increase the efficiency of the operations, reduce the total amount of steps, and reduce overhead from transportation costs. Pellet durability is also a cause for major concern. Low pellet durability can cause a decrease in flowability, a decrease in bulk density, an increased risk of explosions due to airborne dust and an increase in production costs due to the need to recycle pellet fines back into the system for further processing.

Sokhansanj et al. (2006a) detailed the costs, energy inputs, and carbon emissions for biomass collection and preprocessing. They obtained the costs for grinding, pelleting, and cooling and based their assumptions from data provided by Mani et al. (2006). Mani et al. (2006) conducted a study which looked at the specific energy of compacting corn stover into briquettes. This process utilized a single cylinder hydraulic press for the production of pellets. By applying electrical data from processing cellulosic biomass using a ring-style pellet die, a more accurate measurement of the costs for densification could be obtained.

The transportation costs vary with the bulk density of the products being transported, the method of transportation, and the distance from the field to ethanol production center. Sokhansanj et al. (2006b) also outlined costs associated with transporting cellulosic biomass by way of truck, railcars, and pipelines. They noted that the transport costs for trucking and rail did not change with the overall size of the contract. In a live scenario, price breaks would likely be given based on the overall tonnage consumed by the ethanol plants. The rail systems also become a more efficient means for transport over trucking at distance of $110 \mathrm{~km}$ or more. These estimates are dependent on the location of the fields and ethanol plants to the rail systems and the location of railroad substations.

Krishnakumar and Ileleji (2010) also calculated the costs associated with the storage of biomass. These costs vary depending on feedstock variety and plant size. As plant capacity is increased, additional bins are needed for storage but increased throughput allows the operation to become more electrically efficient. While baled cellulosic biomass benefits from the lack of pre-processing costs, as compared to pelleted cellulosic biomass, it requires over twice the amount of storage due to the large amounts of space required.

Pelleting could be used to address transportation and storage issues associated with biomass used for ethanol production. In order to supply cellulosic ethanol plants with 
a year-round supply of materials, multiple biomass varieties will need to be used, due to different harvest times. Energy consumption used for grinding and pelleting is one of the main limiting factors to this infrastructure. The cost for preprocessing of cellulosic biomass will need to be less than the profits gained from increased transportation and storage efficiency.

The objectives of this research were to evaluate (1) the energy requirements of grinding sorghum stalks, corn stover, wheat straw and big bluestem through two different screen size openings, (2) the physical properties of pelleted biomass, (3) the energy requirements of pelleting forages from the two grind sizes, and (4) the costs associated with biomass processing, transportation, and storage.

\section{MATERIALS AND METHODS}

\section{SAMPle Preparation}

Big bluestem was swathed and baled in Beloit, Kansas, in January 2009. The big bluestem bales were donated by Star Seed in Beloit, Kansas. Wheat straw and corn stover bales, produced during 2009, were obtained by the Kansas State University Agronomy Farm from local producers. Photoperiod-sensitive sorghum stalks (Cultivar 'PS 1990, Sorghum Partners, New Deal, Tex.) were harvested by the Kansas State Agronomy Farm in 2008. Wheat straw, big bluestem, and corn stover bales were obtained in $1.82 \times$ $1.22 \times 1.22 \mathrm{~m}$ square bales and the sorghum stalks were obtained in round bales measuring $1.83 \times 1.83 \mathrm{~m}$. Prior to this study, wheat straw, big bluestem, and corn stover bales were stored in covered sheds. Sorghum stalk bales were stored on pallets, under protective tarps.

Particle size reduction of forages was conducted by using a two-stage grinding step. The initial step used a diesel engine powered tub grinder (Haybuster H-1150 series, Duratech, Jamestown, N.D.) to reduce forage particle size. All forages were chopped to a very similar stem length (approximately 17.8 to $22.9 \mathrm{~cm}$ in length). Due to the small amount of forage material ground, accurate measurement of fuel consumed during the initial grinding operation could not be accomplished in this study. Since the study by Hess et al. (2007) yielded ground forages with very similar particle sizes and bulk densities to the product created in this study, the data obtained from their study were therefore used for logistics calculations. Tub-grinder energy values were assumed the same for all biomass types.

Forages were subjected to further particle size reduction through a Schutte Buffalo hammermill Model 18-7-300 (Schutte Buffalo, Buffalo, N.Y.). This hammer mill was a top-fed, teardrop style mill, powered by a three-phase wye wire electrical motor operating at $10 \mathrm{hp}, 3600 \mathrm{rpm}$ and 11.6 A, at $460 \mathrm{~V}$. Product was pre-weighed to $13.6 \mathrm{~kg}$ and placed in separate barrels for each run. Chopped biomass was then manually loaded onto a belt conveyor, which fed into the hammermill. A variable frequency drive (VFD), operated at $30 \mathrm{~Hz}$ of the rated capacity for the belt conveyer, was used to regulate the feed rate. The main challenge at this point of the study was to maintain a similar volumetric feed rate into the hammer mill. It was concluded through a series of preliminary runs that a product bed depth of about $5 \mathrm{~cm}$ on the belt conveyor would provide sufficient product flow without overloading the machine for all forage types. The belt speed was $3.35 \mathrm{~m} / \mathrm{min}$ and the belt width was $28.58 \mathrm{~cm}$.

A $2 \mathrm{hp} \mathrm{Grizzly} \mathrm{air} \mathrm{suction} \mathrm{system} \mathrm{and} \mathrm{cyclone} \mathrm{(Grizzly}$ Industrial Inc., P.N. G0440, Bellingham, Wash.) was attached to the hammer mill to collect the ground forages. The storage container could hold between 13.6 and $15.9 \mathrm{~kg}$ of ground forages, depending on the bulk density. Cellulosic biomass samples were ground using two screen size openings, 3.2 and $6.5 \mathrm{~mm}$. The Grizzly air suction system used a mesh filter to separate fine dust particulates into a separate container. These very fine particles were mixed back into the finished run and the total amount of ground material was weighed. The hammer mill runs were blocked by screen size opening and were randomized and replicated in triplicate.

Electrical data was collected for each run by an Amprobe DM II-Plus (Amprobe, Everett, Wash.) connected to the main power supply for the hammer mill. The Amprobe software was set to collect a set of data points every second. Energy data collected included the power factor, motor load, current across each phase, the average amperage, voltage, and the subsequent watts. Production rate was measured by taking the total amount of recovered ground material over the grinding time. These values were then converted into $\mathrm{kg} / \mathrm{h}$.

Energy consumption rate $(\mathrm{kWh} / \mathrm{t})$ was calculated by taking the observed wattage/1000 (converting it into $\mathrm{kW}$ ) over the production rate, in $\mathrm{kg} / \mathrm{h} / 1000$ (converting it into metric tons per hour).

$$
k W H / \text { metricton }=\frac{\text { ObsWattage } / 1000}{(K g / h) / 1000}
$$

Particle sizes for both the 6.5 and $3.2 \mathrm{~mm}$ grind were obtained using the Penn State Forage Particle Size Analysis (PSFPSA) method (Heinrichs and Kononoff, 2002). The PSFPSA utilizes three separate screens and a pan. After hand sieving, pans were then separated and the amounts on top of the screens were weighed and entered into an Excel spreadsheet to obtain an average particle length and standard deviation centimeters. The spreadsheet has additional functions and graphs used for dairy cattle ration analysis which were not utilized. The ASAE analysis method (ASAE Standards, 2001) indicates that if a ration contains more than $8 \%$ long particles (on the top screen), then the actual average particle size needs to be measured by hand. This is why we also chose to measure the length of the chopped forages. The average length of the particles after grinding was measured using the average lengths of 100 particles. Bulk density was calculated by taking the weight of the full, 35 gal collection chamber after grinding and converted into $\mathrm{kg} / \mathrm{m}^{3}$. Moisture content of the ground forage was determined by drying $25 \mathrm{~g}$ of each sample in a forced-air oven at $103^{\circ} \mathrm{C}$ for $24 \mathrm{~h}$ (ASABE Standards, 2008). Moisture content of corn stover was $7.89 \%$, wheat straw was $7.38 \%$, big bluestem was $7.45 \%$, and sorghum stalks was $9.05 \%$. These moisture values were measured 
post-grinding. The 3.2 and $6.5 \mathrm{~mm}$ ground forages were transported back to the K-State Pilot Feed Mill, located in Shellenberger Hall, Kansas State University to be pelleted.

\section{Biomass Pelleting Process}

The biomass pelleting process was conducted by using a 30 HP Master Model Series 1000 California Pellet Mill (CPM, Crawfordsville, Ind.). Ground forages were fed into the pellet mill through a $454 \mathrm{~kg}$ capacity surge bin located above a conditioner and feeder screw, which metered the product flow. A pneumatic vibratory device was attached to the surge bin to prevent bridging during the runs. Pellets were formed using a $6.35 \times 44.45 \mathrm{~mm}$ die.

Moisture content of the ground forages was increased to $17 \%$ (w.b.) before pelleting. Usually, animal feed diets are conditioned to $16 \%$ to $18 \%$ moisture content to lower energy requirements for pelleting and increase pellet durability. The water was used in place of steam to simulate on-farm pelleting where a boiler is usually not available. Forages were mixed in a custom-built ribbon mixer and water was added with a particulate sprayer. Mixing time for all treatments was $3 \mathrm{~min}$. In a production setting, this step could be conducted using a conditioner with a metered water flow rate. Because small amounts of feedstock materials are required in this study, the ground biomass was conditioned with water in a mixer prior to pelleting process for each experimental run. $11.34 \mathrm{~kg}$ (w.b.) of ground forages were used for each pelleting run.

Pellet mill RPM and feed rate were held constant across all runs. Feed rate was controlled by a variable frequency drive (VFD). The feeder screw is capable of moving a specific volume of product at different RPM. As bulk density value of different types of forages varied, production rates varied and thus influenced energy consumption rate $(\mathrm{kWh} / \mathrm{t})$. Similar to forage grinding, the pellet mill was not limited by motor load, but by the volumetric amount it could process. Pellet runs were blocked by replication and randomized. The individual runs were added by hand into the surge bin above the pellet mill as the spouting and turnhead in the feed mill is designed to handle feed ingredients and is not large enough to accommodate ground forages. This also helped to ensure that the run was completely finished and there was no risk of a previously run forage contaminating another run. The pellet die was cleaned with wheat middlings between each run. This gave a color change and indicated when sample collection could begin. This also aided in the start-up procedure for the ensuing run by ensuring the pellet die holes were filled with a clean-out material.

Electrical data was collected by an Amprobe DM II-Plus (Amprobe, Everett, Wash.) connected to the main power supply for the pellet mill. Energy data collected included the power factor, motor load, current across each phase, the average amperage, voltage and the subsequent wattage. Production rate was measured by taking the total amount of sifted, fully formed pellets over the production time. This allowed us to obtain the production rate of actual pellets being produced and the amount of fines produced. In a typical operation we would expect the fines to be sifted off and reintegrated back into the flow before pelleting. $\mathrm{KWh} / \mathrm{t}$ was calculated by using the same equation (eq. 1) as used for the forage grinding. All pellets were retained for an analysis of pellet durability index (PDI), bulk density and a subsequent fermentation study as part of another trial.

Pellet durability was measured using the tumbling box procedure ASABE S269.4 (2007) and results reported as the PDI. Pellets were collected directly from the pellet mill and cooled with forced air in trays using a locally constructed batch cooler. They were then sieved on a U.S. Number 6 sieve $(3.3528 \mathrm{~mm})$ to remove fines. Two standard and two modified (addition of five $1 / 2$ in. hex nuts) PDI tests were conducted for each production run, and an average value for each was determined. Bulk density of pellets was determined using a Seedburo Model 8860 High Capacity Grain/Test Weight Scale (Seedburo Equipment Co., Des Plaines, Ill.). Three bulk density samples were taken for each of the pelleted forages during each production run, and the values were averaged.

\section{Data Analysis}

The grinding and pelleting experiments were run as a split plot randomized design (SPRD), with the screen size opening as the whole plot and the forage type as the sub plot. The grinding order/pelleting order of forage types was randomized and the runs within each replication were completed within a four hour time frame. Three replications of each treatment were conducted, with each replication being a single production run. Data for bulk density values, production rates, durability value (PDI) and energy consumption rate were analyzed using SAS software (version 9.1, SAS Institute Inc., Cary, N.C.) using the Mixed Procedure. Treatments were compared using LS Means. Using the SPRD, the impact of the screen size opening and forage type on the significance of the data comparison could be determined.

\section{Cost Analysis}

After all data was gathered regarding bulk density and processing cost, those values were applied into a production scenario to determine the processing, transportation, and storage costs of each forage. These values were determined based on variables such as truck capacity, fuel efficiency of vehicles and additional maintenance and operating costs of vehicles. The maintenance and operating costs were calculated using a form provided by Iowa State University (Iowa State University Extension, 2011).

The total energy costs for forage processing ( $\mathrm{kWh} / \mathrm{ton})$ were calculated by adding energy used for tub grinding (Hess et al., 2007), hammer milling, and pelleting. These values were applied to the industrial electricity price for Kansas to generate a dollar amount. Additional capital and operating costs based on published information (Sokhansanj et al., 2006b) were also included to provide a more accurate representation for the total costs for material processing.

As bulk density is one of the main limiting factors in transportation and logistics, we wanted to include a cost structure that accounts for the differences in bulk density based on processing. The USDA Weekly Grain Transporta- 
tion Report (USDA, 2013) stated that for the week ending 9 May 2013 diesel prices in the Midwest were on average $\$ 3.85 /$ gal. The fuel mileage for loaded grain tractor/trailer ranges from 5 to $8 \mathrm{mpg}$.

Costs for storage were calculated by determining the bin space requirement for enough on-hand feedstock for 10 days of operation at 378.5 million liters per year (MLPY) ethanol plant (Krishnakumar and Ileleji, 2010). These values account for varying bulk density of pellets and were compared to costs for baled biomass determined by Krishnakumar and Ileleji (2010) and the costs for corn grain storage.

\section{RESULTS AND DISCUSSION ENERGY CONSUMPTION}

Table 1 shows the electrical energy costs for hammer milling different forages through the two separate screen size openings. The values represented in the table are averages of the three replications. The power factor and motor load varied slightly between forage types and grind sizes but were consistent with their corresponding values for $\mathrm{kWh} / \mathrm{t}$.

The screen size had a significant effect on energy consumptions $(\mathrm{P}<0.05)$. The grinding energy consumption significantly decreased as screen size increased. For example, the grinding energy consumption decreased from $28.13-38.58 \mathrm{kWh} /$ ton to $13.67-14.07 \mathrm{kWh} /$ ton with average energy reduction of about $41 \%$ (table 1 ). In addition, the particle size also affected average power factor $(0.77$ vs. 0.74 ) and average motor load (41.92 vs. 40.63). All four of the forage types, with the exception of big bluestem versus corn stover $(\mathrm{P}>0.05)$, were significantly different in energy consumptions $(\mathrm{P}<0.05)$. All of the 3.2 versus $3.2 \mathrm{~mm}$ and 3.2 versus $6.5 \mathrm{~mm}$ grinds were significantly different from each other $(\mathrm{P}<0.05)$. There was no significant difference between the $6.5 \mathrm{~mm}$ grinds $(\mathrm{P}>0.05)$.

Table 2 shows the electrical energy costs for pelleting forages. The two grind sizes showed significant difference in energy consumptions $(\mathrm{P}<0.05)$. In general, large screen size consumed more energy than small screen size. The average energy increase as particle size increased from 3.2 to $6.5 \mathrm{~mm}$ is $28 \%$. In addition, the particle size also

Table 1. Electrical energy costs for hammer milling forages.

\begin{tabular}{|c|c|c|c|c|}
\hline Screen & Forage $^{[\mathrm{a}]}$ & $\begin{array}{l}\text { Avg. }(\mathrm{n}=2) \\
(\mathrm{kWh} / \\
\text { metric ton) }\end{array}$ & $\begin{array}{l}{ }_{\text {Avg. }}(\mathrm{n}=2) \\
\text { Power } \\
\text { Factor }\end{array}$ & $\begin{array}{l}\text { Avg. } \\
\text { \% Motor } \\
\text { Load }\end{array}$ \\
\hline \multirow{4}{*}{$3.2 \mathrm{~mm}^{\mathrm{a}}$} & Corn Stover $^{\mathrm{a}}$ & $38.58^{\mathrm{a}}$ & 0.78 & 43.48 \\
\hline & Sorghum Stalks ${ }^{b}$ & $32.26^{\mathrm{b}}$ & 0.77 & 42.69 \\
\hline & Big Bluestem $^{\mathrm{a}}$ & $36.88^{\mathrm{a}}$ & 0.77 & 41.93 \\
\hline & Wheat Straw ${ }^{\mathrm{c}}$ & $28.13^{\mathrm{c}}$ & 0.74 & 39.63 \\
\hline Avg. of $3.2 \mathrm{~mm}$ & & 33.96 & 0.77 & 41.92 \\
\hline \multirow{4}{*}{$6.5 \mathrm{~mm}^{\mathrm{b}}$} & Corn Stover $^{a}$ & $14.07^{d}$ & 0.78 & 43.98 \\
\hline & Sorghum Stalks ${ }^{b}$ & $13.67^{\mathrm{d}}$ & 0.76 & 42.46 \\
\hline & Big Bluestem $^{a}$ & $13.49^{d}$ & 0.74 & 39.99 \\
\hline & Wheat Straw $^{\mathrm{c}}$ & $14.00^{\mathrm{d}}$ & 0.69 & 36.10 \\
\hline Avg. of $6.5 \mathrm{~mm}$ & & 13.81 & 0.74 & 40.63 \\
\hline $\begin{array}{l}\text { Avg. energy } \\
\text { difference (\%) }\end{array}$ & $3.2 \mathrm{~mm} / 6.5 \mathrm{~mm}$ & $-41 \%$ & -4.1 & -3.4 \\
\hline
\end{tabular}

Table 2. Electrical energy costs for pelleting ground forages.

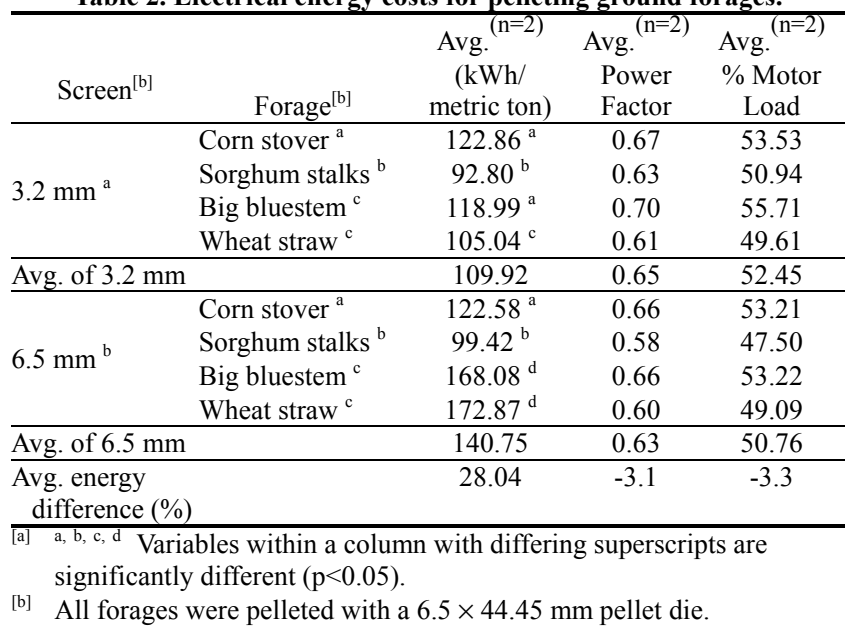

affected average power factor ( 0.65 vs. 0.63$)$ and average motor load (52.45 vs. 50.76). The type of forages also had significant effects on energy consumptions $(\mathrm{P}<0.0001)$ except big bluestem versus wheat straw $(\mathrm{P}>0.05)$. Of the comparisons, $3.2 \mathrm{~mm}$ big bluestem versus $3.2 \mathrm{~mm}$ corn stover, $3.2 \mathrm{~mm}$ big bluestem versus $6.5 \mathrm{~mm}$ corn stover, $3.2 \mathrm{~mm}$ corn stover versus $6.5 \mathrm{~mm}$ corn stover, $3.2 \mathrm{~mm}$ sorghum stalks versus $6.5 \mathrm{~mm}$ sorghum stalks, $3.2 \mathrm{~mm}$ wheat straw versus $6.5 \mathrm{~mm}$ sorghum stalks and $6.5 \mathrm{~mm}$ big bluestem versus $6.5 \mathrm{~mm}$ wheat straw were not significant $(\mathrm{P}>0.05)$. All other comparisons were significantly different $(\mathrm{P}<0.05)$.

Production rate was relatively similar for both grind sizes. However, the $6.5 \mathrm{~mm}$ big bluestem and $6.5 \mathrm{~mm}$ wheat straw had lower production rates due to inconsistent flow and bridging. This is the cause for the higher kilowatt hour per metric ton for these two forages. It appeared that the cohesive nature of the wheat straw and big bluestem was compounded during flow when left at a larger particle size. This is possibly due to the flat plate-like structures present in the larger grinds versus a more granular appearance in the finer grinds. Throughput and consistent flow are both very important attributes to an industrial production process. This could represent a possible shortcoming for the energy savings we gain by leaving particle size larger for the wheat straw and big bluestem. A visual analysis of corn stover and sorghum stalk indicated that flow was relatively similar for both grind sizes.

\section{Physical Properties of Ground Forages}

Table 3 outlines the bulk density characteristics and the production rates of the forages through different screen size openings. The production rate through the $6.5 \mathrm{~mm}$ screen was almost three times higher than that of the $3.2 \mathrm{~mm}$ screen (average of $181.4 \mathrm{vs.} 68 \mathrm{~kg} / \mathrm{h}$ ). The increased screen size from 3.2 to $6.5 \mathrm{~mm}$ allows for a greater volume of forages to be passed through, the consequence is an increased particle size. Screen size had a significant impact not only on throughput, but also the $\mathrm{kWh} / \mathrm{t}$. In industry, the hammer mills typically operate at over $90 \%$ motor load. However, the motor load of hammer mill used in this study was less than $60 \%$ as the aim was to maximize the amount 
Table 3. Bulk densities, production rates and particle sizes of ground forages.

\begin{tabular}{|c|c|c|c|c|}
\hline Screen & Forage & $\begin{array}{l}\text { Avg. } \\
\text { Bulk Density } \\
\left(\mathrm{kg} / \mathrm{m}^{3}\right)^{[\mathrm{a}]}\end{array}$ & $\begin{array}{c}\text { Avg. }(\mathrm{n}=2) \\
\text { Production Rate } \\
(\mathrm{kg} / \mathrm{h})\end{array}$ & $\begin{array}{l}\text { Avg. }(\mathrm{n}=100) \\
\text { Length } \\
(\mathrm{cm})\end{array}$ \\
\hline \multirow{4}{*}{ Chopped } & Corn stover & $41.00^{\mathrm{a}}$ & N/A & $16.5 \pm 0.35$ \\
\hline & Sorghum stalks & $47.74^{\mathrm{a}}$ & N/A & $16.5 \pm 0.90$ \\
\hline & Big bluestem & $37.64^{\mathrm{a}}$ & N/A & $17.8 \pm 0.52$ \\
\hline & Wheat straw & $38.44^{\mathrm{a}}$ & N/A & $17.8 \pm 0.43$ \\
\hline \multirow{4}{*}{$3.2 \mathrm{~mm}$} & Corn stover & $121.90^{b}$ & $68.22^{b}$ & $0.15 \pm 0.083$ \\
\hline & Sorghum stalks & $161.31^{\mathrm{c}}$ & $86.09^{c}$ & $0.15 \pm 0.093$ \\
\hline & Big bluestem & $118.06^{\mathrm{d}}$ & $72.39^{b, c}$ & $0.15 \pm 0.080$ \\
\hline & Wheat straw & $105.08^{e}$ & $86.91^{\mathrm{c}}$ & $0.18 \pm 0.079$ \\
\hline \multirow{4}{*}{$6.5 \mathrm{~mm}$} & Corn stover & $74.65^{f}$ & $203.48^{d}$ & $0.25 \pm 0.084$ \\
\hline & Sorghum stalks & $100.44^{\mathrm{g}}$ & $198.22^{\mathrm{d}, \mathrm{e}}$ & $0.20 \pm 0.098$ \\
\hline & Big bluestem & $75.77^{f}$ & $183.52^{\mathrm{e}}$ & $0.31 \pm 0.077$ \\
\hline & Wheat straw & $76.41^{f}$ & $148.05^{\mathrm{f}}$ & $0.31 \pm 0.075$ \\
\hline
\end{tabular}

of volume a machine can process instead of maximizing the tonnage (table 2). Within the $3.2 \mathrm{~mm}$ grind size, the production rates of the corn stover and big bluestem were significantly different from the production rates of the sorghum stalks and wheat straw $(\mathrm{P}<0.05)$. For the $6.5 \mathrm{~mm}$ screen size opening, all forages differed significantly from the wheat straw, but corn stover versus big bluestem was the only other comparison that differed significantly $(\mathrm{P}<0.05)$.

It was found that bulk density significantly $(\mathrm{P}<0.05$ or less) varied not only between grind sizes, but also varied among most forages within the screen size opening. The chopped forages all yielded very similar results in bulk densities, but they did differ dramatically from the two grind sizes, which is to be expected since chopping was the initial grinding step. Sorghum stalks differed from all other forage types significantly within the $6.5 \mathrm{~mm}$ grind size $(\mathrm{P}<0.05)$, while within the $3.2 \mathrm{~mm}$ grind all of the forage comparisons were significant. This result leads us to believe that as the particle size became smaller, the natural characteristics of the individual forages are being compounded. Meaning that because of the nature of wheat straw (hollow stems) it will naturally be less dense at a finer particle size than a heavy material such as sorghum stalks.

Table 3 also contains the particle size for the individual forage grinds. Chopped lengths were obtained by physically measuring the length of the stalks. Although the length did not vary much between the grind sizes, visual analysis indicated that there was a difference among particle shape and size distribution among different forage types. This is supported by the differences in energy usage and production rate.

\section{Physical Properties of Pelleted Forages}

Bulk density values of pelleted forages are represented in table 4. Statistical analysis showed a significant difference between the two screen size openings $(\mathrm{P}<0.0001)$. The $6.5 \mathrm{~mm}$ grind produced denser pellets than the $3.2 \mathrm{~mm}$ grind. Sorghum stalk pellets, of both the 3.2 and $6.5 \mathrm{~mm}$ grinds showed the lowest bulk densities of 499.46 and $515.79 \mathrm{~kg} / \mathrm{m}^{3}$, respectively.
Table 4. Bulk densities and production rates of pelleted forages.

\begin{tabular}{cccc}
\hline $\begin{array}{c}\text { Screen } \\
(\mathrm{mm})\end{array}$ & Forage $^{[\mathrm{a}]}$ & $\begin{array}{c}\text { Avg. } \\
\text { Bulk }\end{array}$ & $\begin{array}{c}\text { Avg. } \\
\text { Bensity }\end{array}$ \\
\hline \multirow{3}{*}{3.2} & Corn stover $^{\left(\mathrm{kg} / \mathrm{m}^{3}\right)^{[\mathrm{b}]}}$ & $\begin{array}{c}\text { Production Rate } \\
(\mathrm{kg} / \mathrm{h})\end{array}$ \\
& Sorghum stalks & $638.50^{\mathrm{a}}$ & $101.35^{\mathrm{a}}$ \\
& Big bluestem & $699.46^{\mathrm{b}}$ & $120.63^{\mathrm{b}}$ \\
& Wheat straw & $590.85^{\mathrm{a}}$ & $112.77^{\mathrm{c}}$ \\
\hline \multirow{2}{*}{6.5} & Corn stover & $701.13^{\mathrm{d}}$ & $101.40^{\mathrm{a}}$ \\
& Sorghum stalks & $515.79^{\mathrm{b}}$ & $103.24^{\mathrm{a}}$ \\
& Big bluestem & $651.63^{\mathrm{a}, \mathrm{e}}$ & $94.66^{\mathrm{a}}$ \\
& Wheat straw & $679.98^{\mathrm{d}, \mathrm{e}}$ & $72.19^{\mathrm{d}}$ \\
\hline
\end{tabular}

[a] All forages were pelleted with a $6.5 \times 44.45 \mathrm{~mm}$ pellet die.

[b] a, b, c, d, e Variables within a column with differing superscripts are significantly different $(\mathrm{p}<0.05)$.

Comparisons of the bulk density increases from ground forages to pelleted forages are all significant $(\mathrm{P}<0.05)$ and increase up to 3 to 9 folds, depending on the forage type. This increase in bulk density will not only improve the flow characteristics of the forages, but also maximize truck payloads. It has been reported that the factors that increase pellet durability would also increase pellet density (Kaliyan and Morey, 2009). Based on our data, incoming biomass grind size has a significant effect on bulk density.

The sorghum stalk pellets were less durable than other types of forages and as a result more fines were produced. During the pelleting process, sorghum pellets tended to not compact as well as the others and tended to have large fissures along the length of the pellet. They also showed a tendency to expand and lose shape, relative to the other pellets, during the cooling process. This is not to say that sorghum pellets would be the worst option for a production process. Bulk density and pellet durability must be evaluated with consideration to the cost and grinding and producing pellets, and sorghum yielded some of the best energy efficiencies of all forages.

Table 5 presents both the average standard and average modified pellet durability indexes (PDI) for all forages of both grind sizes. Pellet durability was tested using the tumble box method. Statistical analysis showed that there was a significant difference between the sorghum pellets and all other forage types for both grind sizes $(\mathrm{P}<0.05)$. With the exception of sorghum pellets (92\%-93\%), all pellets were above $96 \%$ PDI. Practical analysis states that a difference of less than 5\% PDI is not significant in real

Table 5. Pellet durability indexes of pelleted forages.

\begin{tabular}{|c|c|c|c|}
\hline Screen $^{[\mathrm{a}]}$ & Forage $^{[\mathrm{a}][\mathrm{b}]}$ & $\begin{array}{l}\text { Avg. }(\mathrm{n}=2) \\
\text { Standard PDI } \%{ }^{[\mathrm{c}]}\end{array}$ & $\begin{array}{l}\text { Avg. }(\mathrm{n}=2) \\
\text { Modified PDI\% }{ }^{[\mathrm{d}]}\end{array}$ \\
\hline \multirow{4}{*}{$3.2 \mathrm{~mm}^{\mathrm{a}}$} & Corn stover & $97.43^{a}$ & $97.30^{\mathrm{a}}$ \\
\hline & Sorghum stalks & $92.20^{\mathrm{b}}$ & $91.60^{b}$ \\
\hline & Big bluestem & $97.00^{\mathrm{a}}$ & $96.40^{\mathrm{a}}$ \\
\hline & Wheat straw & $96.80^{\mathrm{a}}$ & $96.2^{\mathrm{a}}$ \\
\hline \multirow{4}{*}{$6.5 \mathrm{~mm}^{\mathrm{b}}$} & Corn stover & $98.00^{\mathrm{a}}$ & $97.30^{\mathrm{a}}$ \\
\hline & Sorghum stalks & $96.00^{\mathrm{a}}$ & $94.20^{\mathrm{c}}$ \\
\hline & Big bluestem & $97.40^{\mathrm{a}}$ & $96.80^{\mathrm{a}}$ \\
\hline & Wheat straw & $98.00^{\mathrm{a}}$ & $97.58^{\mathrm{a}}$ \\
\hline \multicolumn{4}{|c|}{$\begin{array}{l}\text { All forages were pelleted with a } 6.5 \times 44.45 \mathrm{~mm} \mathrm{pe} \\
\text { PDI tests were conducted for each production run. }\end{array}$} \\
\hline $\begin{array}{ll}\text { [c] } & \text { a, b, c } \\
& \text { signifi } \\
\text { [d] } & \text { Modif }\end{array}$ & \multicolumn{3}{|c|}{$\begin{array}{l}\text { Variables within a column with differing superscripts are } \\
\text { icantly different }(p<0.05) \text {. }\end{array}$} \\
\hline
\end{tabular}


world applications. All pellets displayed very high pellet durability relative to expected durability standards.

Hot pellet temperatures and percent fines were also measured for each of the pellet runs. Hot pellet temperatures are obtained by filling a Styrofoam container full of pellets straight from the pellet mill chute and immediately placing a lid on top of the bucket with a temperature probe inserted. The highest value on the temperature probe is recorded as the hot pellet temperature. The temperature change between the forages before the pelleting process and after the pelleting process gives us an indication of the heat transfer between the die and forages.

No significant differences between the hot pellet temperatures of grind sizes or forage types were observed. The biomass temperature increased from $25^{\circ} \mathrm{C}$ before pelleting to between $76^{\circ} \mathrm{C}$ and $82^{\circ} \mathrm{C}$ after pelleting. The large increase in biomass temperature could possibly have an effect on the breakdown of cellulosic fibers and the end fermentation process. It would also necessitate the use of a cooling system if pellets were meant to be kept in long term storage. As observed in the preliminary study, pellet fines were between $5 \%$ and $8 \%$. There were no significant differences for pellet fines percentage between forage types and grind sizes.

\section{EFFECT OF DENSIFICATION ON LOGISTICAL COSTS}

Table 6 outlines the effect of bulk density on the transportation efficiency, specifically the differences between corn grain, baled biomass, and pelleted biomass. The efficiency of transportation increased as bulk density increased and thereby decreased the total volume of trucks needed to supply an ethanol plant with the required feedstock. This has a trickledown effect causing decreased wear and maintenance costs for both the trucks and also for the unloading equipment. With the exception of sorghum pellets, all other forage pellets were around $650 \mathrm{~kg} / \mathrm{m}^{3}$, which would further decrease the size of the storage bins needed or increase the amount of on-hand inventory plants could hold. Fuel mileage also needs to be taken into account, as most commercial semi-trucks will range from between 5 and 8 MPG.
Just over 5000 metric tons per day will be required for the operation of a 378.5 MLPY ethanol plant. Assuming a semi-truck can hold $37.75 \mathrm{~m}^{3}$; the daily amount of trucks required will be 184 for corn grain, 314 for baled biomass, and 207 for $6.5 \mathrm{~mm}$ ground corn stover (which has the highest bulk density of all pelleted biomass sources). All pelleted biomass sources require less truck traffic than baled biomass sources, making it a much more realistic option based on incoming volume of trucks and unloading time required.

Table 7 shows the energy values required for grinding and pelleting. Initial capital and operational costs, referenced from Sokhansanj et al. (2006b), are added to the measured values to give a better estimate for the biomass pelleting cost. Wheat straw and big bluestem ground through a $3.2 \mathrm{~mm}$ screen used more total energy (grinding energy and pelleting energy combined) than that ground through a $6.5 \mathrm{~mm}$ screen (by $\$ 3.44 /$ metric ton and $\$ 1.87 /$ metric ton, respectively). Corn stover and sorghum stalks ground through the $6.5 \mathrm{~mm}$ screen were the most energy efficient forages, at $\$ 28.76$ and $\$ 27.25 /$ metric ton.

Many of the cost saving measures suggested by Sokhansanj et al. (2006 a) are also relevant to this study. Increasing the production capacity of our machinery would decrease the $\mathrm{kWh} / \mathrm{t}$ and increasing the frequency of machinery usage. It should also be noted that the pellet mill used in our study is the smallest production model manufactured by CPM. Pellet mill energy usage accounted for $20 \%$ to $32 \%$ of the total costs of grinding and pelleting. By doubling our efficiency by switching to a larger pellet mill, we could reduce the cost/metric ton by up to $\$ 5.28$.

The total costs of biomass preprocessing, incoming transportation costs, and costs of storage and unloading are presented in table 8 . The low costs of transporting corn grain, baled biomass, and the averages of all pellets are $\$ 27.95 /$ metric ton, \$102.36/metric ton, and \$50.91/metric ton, respectively. The high costs of transporting corn grain, baled biomass, and the averages of all pellets are $\$ 28.53 /$ metric ton, $\$ 103.06 /$ metric ton, and \$51.91/metric ton, respectively.

The high cost accounts for $5 \mathrm{MPG}$ in tractor/trailers and the low cost accounts for $8 \mathrm{MPG}$ in tractor/trailers.

Table 6. Impact of bulk density on transportation costs.

\begin{tabular}{|c|c|c|c|c|c|c|c|c|c|c|}
\hline & \multirow[b]{2}{*}{$\begin{array}{l}\text { Corn } \\
\text { Grain }\end{array}$} & \multirow[b]{2}{*}{$\begin{array}{c}\text { Baled } \\
\text { Biomass }\end{array}$} & \multicolumn{4}{|c|}{ Pellets from $3.2 \mathrm{~mm}$ Grind } & \multicolumn{4}{|c|}{ Pellets from $6.5 \mathrm{~mm}$ Grind } \\
\hline & & & $\begin{array}{l}\text { Wheat } \\
\text { Straw }\end{array}$ & $\begin{array}{l}\text { Sorghum } \\
\text { Stalks }\end{array}$ & $\begin{array}{c}\text { Big } \\
\text { Bluestem }\end{array}$ & $\begin{array}{l}\text { Corn } \\
\text { Stover }\end{array}$ & $\begin{array}{l}\text { Wheat } \\
\text { Straw }\end{array}$ & $\begin{array}{l}\text { Sorghum } \\
\text { Stalks }\end{array}$ & $\begin{array}{c}\text { Big } \\
\text { Bluestem }\end{array}$ & $\begin{array}{l}\text { Corn } \\
\text { Stover }\end{array}$ \\
\hline Bulk density $\left(\mathrm{kg} / \mathrm{m}^{3}\right)$ & 720.83 & $150.57^{[\mathrm{a}]}$ & 590.76 & 499.46 & 629.85 & 638.50 & 679.98 & 515.79 & 651.63 & 701.13 \\
\hline Truckload weight (metric tons) ${ }^{[\mathrm{b}]}$ & 27.27 & $16.00^{[\mathrm{a}]}$ & 22.35 & 18.90 & 23.82 & 24.16 & 25.73 & 19.52 & 24.66 & 26.53 \\
\hline Fuel price $(\$ /$ mile/metric ton $)$ at $5 \mathrm{MPG}^{[\mathrm{c}]}$ & 0.0238 & 0.0238 & 0.0238 & 0.0238 & 0.0238 & 0.0238 & 0.0238 & 0.0238 & 0.0238 & 0.0238 \\
\hline Fuel price $(\$ /$ mile/metric ton $)$ at $8 \mathrm{MPG}^{[\mathrm{c}]}$ & 0.0149 & 0.0149 & 0.0149 & 0.0149 & 0.0149 & 0.0149 & 0.0149 & 0.0149 & 0.0149 & 0.0149 \\
\hline Equipment/ Operating costs $(\$ / \text { mile })^{[\mathrm{d}]}$ & 0.4310 & 0.4310 & 0.4310 & 0.4310 & 0.4310 & 0.4310 & 0.4310 & 0.4310 & 0.4310 & 0.4310 \\
\hline Price of $100 \mathrm{miles} /$ truck at $5 \mathrm{MPG}$ & 108.05 & 81.21 & 96.33 & 88.12 & 99.83 & 100.64 & 104.38 & 89.59 & 101.84 & 106.29 \\
\hline Price of $100 \mathrm{miles} /$ truck at $8 \mathrm{MPG}$ & 92.30 & 92.38 & 76.42 & 71.28 & 78.61 & 79.12 & 81.46 & 72.20 & 79.87 & 82.65 \\
\hline Number of trucks for 5000 metric tons & 184 & 314 & 246 & 291 & 231 & 228 & 214 & 282 & 223 & 207 \\
\hline $\begin{array}{l}\text { Incoming costs } \$ \text { at } 5 \text { MPG for } 5000 \text { metric } \\
\text { tons }\end{array}$ & 19849.19 & 28961.13 & 23706.26 & 25642.33 & 23051.72 & 22911.67 & 22312.98 & 5243.95 & 22712.73 & 22035.17 \\
\hline $\begin{array}{l}\text { Incoming costs } \$ \text { at } 8 \mathrm{MPG} \text { for } 5000 \text { metric } \\
\text { tons }\end{array}$ & 16955.51 & 25459.05 & 18806.26 & 20742.33 & 18151.72 & 18011.67 & 17412.98 & 20343.95 & 517812.73 & 17135.17 \\
\hline $\begin{array}{l}\text { a] Source: Krishnakumar and Ileleji (2010). } \\
\text { [b] Assuming Truck Volume of } 37.75 \mathrm{~m}^{3} . \\
\text { [c] Diesel Price of } \$ 3.942 / \text { gal. } \\
\text { [d] Source: ISU Extension (2011). }\end{array}$ & & & & & & & & & & \\
\hline
\end{tabular}


Table 7. Energy costs of grinding and pelleting biomass.

\begin{tabular}{|c|c|c|c|c|c|c|c|c|}
\hline & \multicolumn{4}{|c|}{$3.2 \mathrm{~mm}$ Grind } & \multicolumn{4}{|c|}{$6.5 \mathrm{~mm}$ Grind } \\
\hline & Wheat & Sorghum & Big & Corn & Wheat & Sorghum & Big & Corn \\
\hline & Straw & Stalks & Bluestem & Stover & Straw & Stalks & Bluestem & Stover \\
\hline $\mathrm{kWh} / \mathrm{t}$ tub grinding ${ }^{[\mathrm{a}]}$ & 36.19 & 36.19 & 36.19 & 36.19 & 36.19 & 36.19 & 36.19 & 36.19 \\
\hline $\mathrm{kWh} / \mathrm{t}$ grinding (hammer milling) & 28.13 & 32.26 & 36.88 & 38.58 & 14.00 & 13.67 & 13.49 & 14.07 \\
\hline $\mathrm{kWh} / \mathrm{t}$ pelleting & 105.04 & 92.80 & 118.99 & 122.86 & 172.87 & 99.42 & 168.08 & 122.58 \\
\hline Total kWh/t & 169.36 & 161.25 & 192.06 & 197.63 & 223.06 & 149.28 & 217.76 & 172.84 \\
\hline Energy cost $\$^{[\mathrm{b}]}$ & 10.86 & 10.34 & 12.31 & 12.67 & 14.3 & 9.57 & 13.96 & 11.08 \\
\hline Additional capital costs $\$^{[\mathrm{c}]}$ & 2.97 & 2.97 & 2.97 & 2.97 & 2.97 & 2.97 & 2.97 & 2.97 \\
\hline Additional operating costs $\$^{[c]}$ & 14.71 & 14.71 & 14.71 & 14.71 & 14.71 & 14.71 & 14.71 & 14.71 \\
\hline Total cost/metric ton $\$$ & 28.54 & 28.02 & 29.99 & 30.35 & 31.98 & 27.25 & 31.64 & 28.76 \\
\hline
\end{tabular}

Table 8. Processing, transportation and storage costs of cellulosic biomass to ethanol plants.

\begin{tabular}{|c|c|c|c|c|c|c|c|c|c|c|}
\hline & \multirow[b]{2}{*}{$\begin{array}{l}\text { Corn } \\
\text { Grain }\end{array}$} & \multirow[b]{2}{*}{$\begin{array}{c}\text { Baled } \\
\text { Biomass }\end{array}$} & \multicolumn{4}{|c|}{$3.2 \mathrm{~mm}$ Grind } & \multicolumn{4}{|c|}{$6.5 \mathrm{~mm}$ Grind } \\
\hline & & & $\begin{array}{l}\text { Wheat } \\
\text { Straw }\end{array}$ & $\begin{array}{l}\text { Sorghum } \\
\text { Stalks }\end{array}$ & $\begin{array}{c}\text { Big } \\
\text { Bluestem }\end{array}$ & $\begin{array}{l}\text { Corn } \\
\text { Stover }\end{array}$ & $\begin{array}{l}\text { Wheat } \\
\text { Straw }\end{array}$ & $\begin{array}{l}\text { Sorghum } \\
\text { Stalks }\end{array}$ & $\begin{array}{c}\text { Big } \\
\text { Bluestem }\end{array}$ & $\begin{array}{l}\text { Corn } \\
\text { Stover }\end{array}$ \\
\hline Processing costs (\$/metric ton) (table 7$)$ & $\mathrm{N} / \mathrm{A}$ & $19.47^{[\mathrm{a}]}$ & 28.54 & 28.02 & 29.99 & 30.35 & 31.98 & 27.25 & 31.64 & 28.76 \\
\hline High incoming costs $(\$ /$ mile/metric ton) (table 6$)$ & 0.0397 & 0.0579 & 0.0474 & 0.0513 & 0.0461 & 0.0458 & 0.0446 & 0.0505 & 0.0454 & 0.0441 \\
\hline Low incoming costs ( $\$ /$ mile/metric ton) (table 6$)$ & 0.0339 & 0.0509 & 0.0376 & 0.0415 & 0.0363 & 0.0360 & 0.0348 & 0.0407 & 0.0356 & 0.0343 \\
\hline Cost of storage (\$/metric ton $)^{[\mathrm{b}]}$ & 24.56 & 77.80 & 19.87 & 23.50 & 18.64 & 18.38 & 17.26 & 22.76 & 18.01 & 16.74 \\
\hline $\begin{array}{l}\text { Total high cost } 100 \text { mile transport and storage } \\
(\$ / \text { metric ton })^{[c]}\end{array}$ & 28.53 & 103.06 & 51.34 & 54.52 & 51.54 & 51.64 & 52.13 & 52.99 & 52.56 & 48.39 \\
\hline $\begin{array}{l}\text { Total low cost } 100 \text { mile transport and storage } \\
(\$ / \text { metric ton })^{[\mathrm{d}]}\end{array}$ & 27.95 & 102.36 & 50.36 & 53.54 & 50.56 & 50.66 & 51.15 & 52.01 & 51.58 & 47.41 \\
\hline
\end{tabular}

[a] Source: Hess et al. (2007).

[b] Source : Krishnakumar and Ileleji (2010) (accounts for varying bulk density of pellets and 378.5 MLPY plant capacity).

[c] High cost assumes $5 \mathrm{MPG}$ tractor/trailer fuel economy.

[d] Low cost assumes $8 \mathrm{MPG}$ tractor/trailer fuel economy.

Although the cost of transporting pelleted cellulosic biomass is almost twice the cost of transporting corn grain, it is a much more efficient means of transportation than baled biomass.

\section{CONCLUSIONS}

During the course of this study, we confirmed that grind size had a significant impact on electrical energy consumption, bulk density, production rate, and particle size produced. Similar grinding studies have been conducted, but it was necessary in our case to determine the differences between forage types and to establish a baseline to compare electrical energy for the pelleting study.

The $6.5 \mathrm{~mm}$ grind used less than half of the electricity required for the $3.2 \mathrm{~mm}$ grind. Ideally if the pelleting electrical consumptions do not differ and ethanol fermentation is not impacted, we would recommend this grind in the interest of conserving production costs. We must keep in mind we need to consider the total electrical costs for the combination of grinding and pelleting when we make our final assumptions.

Although the cost of transporting pelleted cellulosic biomass is almost twice the cost of transporting corn grain, it is a much more efficient means of transportation than baled biomass. It would be possible to further reduce the costs of pelleting by increasing the total throughput of the machinery, designing machinery specifically for this application or designing the cellulosic ethanol infrastructure to utilize primarily railroads. The prohibitive logistical costs of forages have prevented cellulosic ethanol form becoming a viable competitor in the energy market. By utilizing a variety of feedstocks and a mobile densification process, these logistical shortcomings can be overcome. The results of this study show that through pelleting we are able to significantly decrease the amount of truck traffic and unloading necessary to operate cellulosic ethanol plants, by increasing the bulk density of the incoming product. By optimizing the receiving process of ethanol plants, the man hours required for operation can be reduced, conveying equipment can be utilized to its full potential and bin space within the facility can be maximized. Our study shows that through pelleting, the logistical structure of the cellulosic ethanol industry can be optimized by on-farm densification of the biomass sources.

\section{ACKNOWLEDGMENTS}

The authors are grateful to the Biomass Research and Development Initiative Competitive Grants Program (BRDI), USDA National Institute of Food and Agriculture, Grant No. 68-3A75-7-609 for funding this project. The authors appreciate the research facilities and support provided by Department of Grain Science and Industry. This is contribution number 14-168-J from the Kansas Agricultural Experiment Station.

\section{REFERENCES}

ASABE Standard S269.4. (2007). Cubes, pellets, and crumbles: Definitions and methods for determining density, durability, and moisture content. St. Joseph, Mich.: ASABE.

ASABE Standard S358.2. (2008). Moisture measurement-forages. St. Joseph, Mich.: ASABE. 
ASAE Standard S424. (2001). Method of determining and expressing particle size of chopped forage materials by sieving. St. Joseph, Mich.: ASAE.

Cushman, J. H., Easterly, J. C., Erbach, D. C., Foust, T. D., Hess, J. R., \& Hettenhaus, J. R. (2003). Roadmap for Agriculture Biomass Feedstock Supply in the United States (DOE/NE-ID11129 ed.).

Drzymała, Z. (1993). Industrial Briquetting: Fundamentals and Methods. New York, N.Y.: Elsevier.

Heinrichs, J., \& Kononoff, P. (2002). Evaluating Particle Size of Forages and TMRs using the New Penn State Forage Particle Separator (DAS 02-42 ed.). University Park, Pa.: Pennsylvania State University.

Hess, J. R., Wright, C. T., \& Kenney, K. L. (2007). Cellulosic biomass feedstocks and logistics for ethanol production. Biofuels, Bioproducts and Biorefining, 1(3), 181-190. doi:http://dx.doi.org/10.1002/bbb.26

Hess, J., Kenney, K., Laney, P., Muth, D., Pryfogle, P., \& Radtke, C. (2006). Feasibility of a producer owned ground-straw feedstock supply system for bioethanol and other products (INL/EXT-0611815 ed.).

Iowa State University Extension. (2011). Grain transportation costs. Retrieved from www.extension.iastate.edu/agdm/crops/xls/a329graintransportation.xls

Kaliyan, N., \& Morey, R. (2009). Factors affecting strength and durability of densified biomass products. Biomass Bioenergy, 33(3), 337-359.

doi:http://dx.doi.org/10.1016/j.biombioe.2008.08.005
Krishnakumar, P., \& Ileleji, K. E. (2010). A comparative analysis of the economics and logistical requirements of different biomass feedstock types and forms for ethanol production. Applied Eng. in Agric., 26(5), 899-907. doi:http://dx.doi.org/10.13031/2013.41332

Mani, S., Tabil, L., \& Sokhansanj, S. (2004). Grinding performance and physical properties of wheat and barley straws, corn stover and switchgrass. Biomass and Bioenergy, 27(4), 339-345. doi:http://dx.doi.org/10.1016/j.biombioe.2004.03.007

Mani, S., Tabil, L., \& Sokhansanj, S. (2006). Specific energy requirement for compacting corn stover. Bioresource Technology, 97(12), 1420-1426.

doi:http://dx.doi.org/10.1016/j.biortech.2005.06.019

Mukunda, A. (2007). A simulation based study of biomass transportation logistics in corn stover ethanol conversion (Master's Thesis ed.). West Lafayette, Ind.: Purdue University.

Sokhansanj, S., \& Fenton, J. (2006). Cost benefit of biomass supply and pre-processing (A BIOCAP Research Integration Program, Synthesis Paper, BIOCAP, Canada ed.). Retrieved October 17, 2011, from www.biocap.ca/rif/report/Sokhansanj_S.pdf

Sokhansanj, S., Turhollow, A., Tagore, S., \& Mani, S. (2006). Integrating biomass feedstock with an existing grain handling system for biofuels. ASABE Paper No. 06618 . St. Joseph, Mich.: ASABE.

USDA. (2011). Weekly grain transportation report. Retrieved May 9, 2013, from http://www.ams.usda.gov/AMSv1.0/getfile?dDoc Name$=$ STELPRDC5103806 